\title{
Present and Future of Polymers in Space
}

\author{
A. Rembaum*
}

\section{Introduction}

Polymers are extensively used on spacecraft and are affected by the environment of outer space. Plastics, elastomers, and organic coatings must be tested here on earth and the results extrapolated to space environments. Therefore it is important to bear in mind that the region of space considered is not homogeneous and the composition of the gas at $200 \mathrm{~km}$ from earth is very different from the composition at higher altitudes. Thus the effects of space environment will depend a great deal on the particular orbit of the space vehicle. However, in most space missions three important effects must be considered, namely the effects of radiation, vacuum and temperature.

\section{Radiation}

Two main kinds of radiation are encountered; 1) electromagnetic radiation, or radiation from the sun, the intensity of which varies as the square of the distance from the sun; 2) radiation due to impinging atomic particles, e.g. ions and electrons. This type of radiation originates mainly from the Van Allen belt which extends from a few $\mathrm{km}$ to about a $1,000 \mathrm{~km}$ above the earth.

\section{1-1. Effects of Electromagnetic Radiation}

Approximately half the energy of sunlight lies in the infrared and radio frequency regions, $40 \%$ in the visible $(4,000 \sim 7,000 \AA)$, and $10 \%$ in the ultraviolet and X-ray spectral region. The latter does not pass through the earth's atmosphere but will be encountered in space.

* Jet Propulsion Laboratory California Institute of Technology Pasadena, California

*1 This paper represents one phase of research performed by the Jet Propulsion Laboratory, California Institute of Technology sponsored by the National Aeronautics and Space Administration, Contract NAS 7-100.

Vol. 16 , No, 187
The penetration depth of electromagnetic radiation varies with its wavelength. In the gamma-ray region at wavelength below $10^{-1} \AA$ this may reach $10 \mathrm{~cm}$. For wavelengths between 100 and $1,000 \AA$ penetration in solids is very small $\left(10^{-4}\right.$ to $\left.10^{-7} \mathrm{~cm}\right)$. Near $3,000 \AA$ the penetration into plastics may be again of the order of $10 \mathrm{~cm}$. Photons of 500 to $3,000 \AA$ cause ionization or electronic excitation, i. e. they raise electrons to higher energy states. Sunlight above $3,000 \AA$ is not likely to damage any polymers, thus only the solar radiation that does not reach the earth's surface is of concern. The radiation between $100 \sim 1,000 \AA$ which penetrates layers of $10^{-4}$ to $10^{-7} \mathrm{~cm}$ damages thin layers of all known polymers. The electronic excitation due to the effects of electromagnetic radiation result in formation of free radicals and, consequently, breakdown of polymer chains and crosslinking. Chain breakdown is accompanied by loss of mechanical strength and deterioration of electrical properties. Crosslinking reduces elastic deflection and is therefore not desirable. It eventually embrittles polymers to the point were surface flaking and fracture occur. No direct experiments have been reported on irradiation of polymers with wavelengths of the order of $100 \sim 1,000 \AA$, but experiments on irradiation at 1,000 $\sim 3,000 \AA$ exist. Films of commercial phenyl methyl silicone, vinyl chloride and methyl methacrylate underwent appreciable crosslinking on exposure equivalent to a few days in space sunlight. At exposures corresponding to a week or two in space, polyethylene terephthalate (mylar), plasticized polyvinyl chloride and polytetrafiuoroethylene were discolored and lost much of their mechanical strength and flexibility. In general, radiation in presence of air causes more damage than radiation in vacuum. Also, the exposure time at which a given damage is reached in vacuum may be increased three to ten 
times by addition of stabilizers.

\section{1-2. The Van Allen Radiation Belt}

In the radiation belt, damage results from protons, ions and electrons which penetrate materials to a definite depth. The main effect of particle impact is ionization. The radiation doses producing appreciable change in engineering properties of various polymers are shown in Table 1 . The results of Table 1. are mainly based on effects on elongation since the tensile strength falls off with decrease of elongation.

Some correlations between polymer structure and radiation effects have been established; aro-

Table 1. Radiation Dose Producing Appeciable Change in Engineering Properties of Various Polymers ${ }^{1)}$

\begin{tabular}{|c|c|}
\hline Polymer & $\begin{array}{c}\text { Tonization } \\
\text { (erg/g) }\end{array}$ \\
\hline Styrene, reinforced & $10^{11}$ \\
\hline Vinyl carbazol & $10^{10}$ \\
\hline Silicone resin, reinforced & $10^{10}$ \\
\hline Styrene, unreinforced & $10^{10}$ \\
\hline Ethylene terephthalate, stretched & $10^{10}$ \\
\hline Melamine, reinforced & $10^{9}$ \\
\hline Diphenyl silicone elastomer & $10^{9}$ \\
\hline Ethylene, low density & $10^{9}$ \\
\hline Phenolic, unreinforced & $10^{9}$ \\
\hline Urea formaldehyde, reinforced & $10^{9}$ \\
\hline Natural rubber & $10^{9}$ \\
\hline Vinyl pyridine & $10^{9}$ \\
\hline Vinyl chloride & $10^{9}$ \\
\hline Vinylidene chloride & $10^{9}$ \\
\hline Silicone resin, unreinforced & $10^{9}$ \\
\hline Butadiene-styrene (SBR) & $10^{9}$ \\
\hline Ethylene, high density & $10^{8}$ \\
\hline Propylene & $10^{8}$ \\
\hline Vinylidene fluoride-hexafluoropropene & $10^{8}$ \\
\hline $\begin{array}{l}\text { Chlorotrifluoroethylene-vinylidene } \\
\text { fluoride }\end{array}$ & $10^{8}$ \\
\hline Ester, unreinforced & $10^{8}$ \\
\hline Butadiene-acrylonitrile (nitrile rubber) & $10^{8}$ \\
\hline Butadiene & $10^{8}$ \\
\hline Neoprene (chloroprene) & $10^{8}$ \\
\hline Chlorosulfonated ethylene & $10^{8}$ \\
\hline Acrylic & $10^{8}$ \\
\hline Silicone elastomers (most) & $10^{8}$ \\
\hline Nylon & $10^{8}$ \\
\hline Polyformaldehyde & $10^{7}$ \\
\hline Isobutylene-isoprene (butyl rubber) & $10^{7}$ \\
\hline Silicone elastomer, fluorinated & $10^{7}$ \\
\hline Tetrafluoroethylene & $10^{6}$ \\
\hline
\end{tabular}

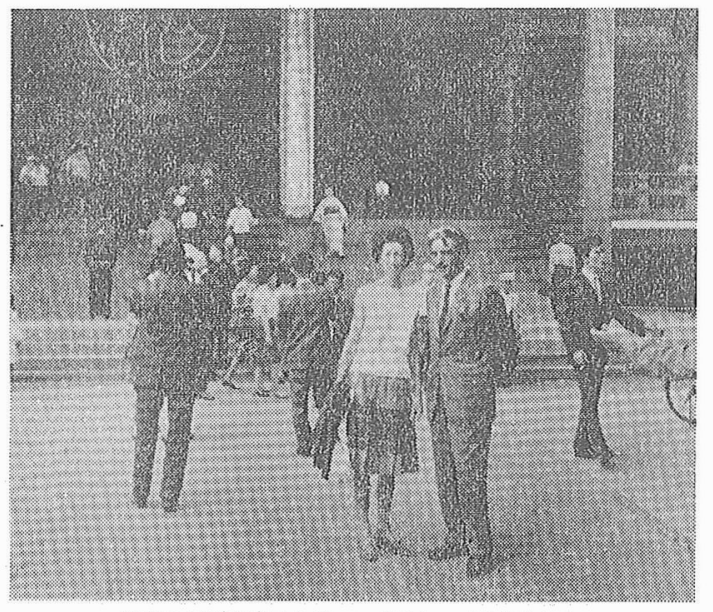

昨年の国際高分子化学シンポジウムで来日されれ

Rembaum 己゙夫妻(浅草雷門にて, 1966. 10. 1)

matic groups in side chains increase radiation stability over that of linear polyethylene, but aromatic groups in the main chain or ether and sulfide linkage decrease stability. Chlorine and fluorine attached to the chain reduce radiation resistance. Silicone chains are as stable as straight carbon chains. ${ }^{2}$

Reinforcement generally increases stability. Reinforced plastics are up to $10^{3}$ times as resistant to radiation as unreinforced plastics, and carbon black improves the radiation resistance of natural rubber. ${ }^{3)}$

\section{Vacuum Effects}

At the altitude of $200 \mathrm{~km}$ the gas pressure is of the order of $10^{-6} \mathrm{~mm} \mathrm{Hg}$ and decreases at higher altitude $\left(10^{-13}\right.$ at $\left.6,500 \mathrm{~km}\right)$. Any low molecular weight compounds such as plasticizers or fragments produced as a result of radiation damage would volatilize. The temperature at which a $10 \%$ weight loss occurs, for a variety of polymers, is tabulated below (Table 2).

The volatilization of materials endangers the function of the spacecraft since the volatiles may redeposit on cool surfaces, e.g. relay contacts and prevent them from closing properly.

The simplest quantitative value which can be obtained for the behavior of a polymer in the thermal-vacuum environment is the loss of weight. This value does not reveal the nature of the components but nevertheless is useful for selecting polymers suitable for spacecraft, since in the majority of instances it may be safely assumed that mechanical or other useful properties of the polymer 
Table 2. Decomposition of Polymers in High Vacuum

\begin{tabular}{|c|c|c|c|}
\hline \multirow[t]{2}{*}{ Polymer } & \multicolumn{2}{|c|}{$\begin{array}{l}\text { Temperature for } 10 \% \\
\text { weight loss per year } \\
\text { in vacuum }\end{array}$} & \multirow{2}{*}{$\begin{array}{l}\text { Literature } \\
\text { references }\end{array}$} \\
\hline & $\left({ }^{\circ} \mathrm{C}\right)$ & $\left({ }^{\circ} \mathrm{F}\right)$ & \\
\hline Nylon & $30-120$ & $80-410$ & 4) \\
\hline Cellulose nitrate & 40 & 100 & 5) \\
\hline Methyl acrylate & $40-150$ & $100-300$ & 6) \\
\hline Vinyl chloride & 90 & 190 & 7) \\
\hline Neoprene (chloroprene) & 90 & 200 & 5) \\
\hline Methyl methacrylate & $100-200$ & $220-390$ & 6) \\
\hline Acrylonitrile & 120 & 240 & 8) \\
\hline Isobutylene-isoprene (butyl rubber) & 120 & 250 & 9) \\
\hline Styrene-butadiene & 130 & 270 & 5) \\
\hline Styrene & $130-220$ & $270-420$ & 6) \\
\hline Butadiene-acrylonitrile (nitrile rubber) & $150-230$ & $300-450$ & 9) \\
\hline Viny1 acetate & 160 & 320 & 10) \\
\hline Cellulose & 180 & 350 & 6) \\
\hline Methyl styrene & $180-220$ & $350-420$ & 6) \\
\hline Cellulose acetate & 190 & 370 & 11) \\
\hline Propylene & $190-240$ & $370-470$ & 6) \\
\hline Isoprene & 190 & 380 & 12) \\
\hline Melamine & 190 & 380 & 13) \\
\hline Silicone elastomer & 200 & 400 & 14) \\
\hline Ethylene terepthalate (mylar, dacron) & 200 & 400 & 15) \\
\hline Isobutylene & 200 & 400 & 6) \\
\hline Vinyl toluene & 200 & 400 & 6) \\
\hline Butadiene-styrene (GR-S $=\mathrm{SBR})$ & 240 & 460 & 6) \\
\hline Vinyl fluoride & 240 & 460 & 16) \\
\hline Ethylene, low density & $240-280$ & $560-540$ & 6) \\
\hline Butadiene & 250 & 490 & 12) \\
\hline Chlorotrifluoroethylene & 250 & 490 & 6) \\
\hline Vinylidene fluoride & 270 & 510 & 16) \\
\hline Ethylene, high density & 290 & 560 & 6) \\
\hline Tetrafluoroethylene & 380 & 710 & 16) \\
\hline
\end{tabular}

are degraded when a substantial loss of weight has been incurred. It is customary to assume that polymeric substances which lose less than $1 \%$ of their weight in a thermalvacuum environment may be ordinary gases (e. g. adsorbed air or carbon dioxide), and liquids of high vapor-pressure (e. g. lubricating oils, plasticizers). In order to select polymeric materials for Mariner IV (successful Mars probe) a volatile-condensable material (VCM) test was applied. The VCM test is a measure of the volatile materials given off by a polymer that will condense on a cooler surface. A VCM value of less than $0.5 \times 10^{-4} \mathrm{gm}$ of condensables per square inch of sample material area was considered acceptable. Over one hundred different polymers were used,

Vol. 16, No. 187 after screening, in the Mariner IV spacecraft. These included teflon for wire insulation, and $\mathrm{MoS}_{2}$ -impregnated nylon in the TV camera system; asbestos-filled epoxy adhesives and room temperature vulcanizing (RTV) silicone adhesive for the solar panels, polyvinylfluoride for cabling, multilayered aluminized mylar for thermal shields, etc. ${ }^{17)}$ The successful mission of Mariner IV shows that the above polymers are suitable for rereatively long space flights.

\section{Temperature}

The exploration of outer space requires materials that would withstand high temperatures, as well as cryogenic materials, i. e. those used for equipment 
and structures subjected to extremely low temperatures.

\section{3-1. High Temperature Polymers}

The requirements of space technology led to exciting new discoveries in the area of heat resistant polymers. Significantly higher thermal stability is obtainable from polymeric systems comprised of heterocyclic recurring units. ${ }^{18)}$ The following sketches indicate the types of polymers already available commercially, and the upper temperature limits of their usability. ${ }^{19}$

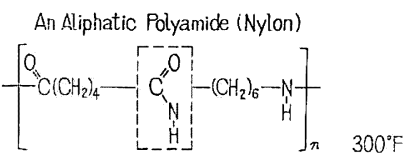

An Aromatic Polyamide (Nomex)

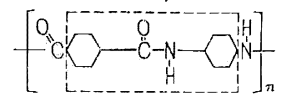

An Armatic Polyimide (SKYGARD)

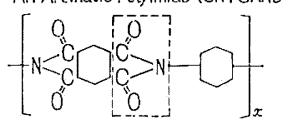

$550^{\circ} \mathrm{F}$

A Polybensimidazole (IMIDITE)

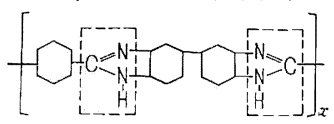

$700^{\circ} \mathrm{F}$

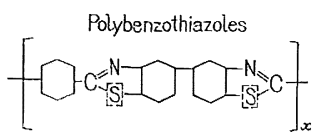

$900^{\circ} \mathrm{F}$

The thermal stability of the above polymers is due to their continuous chain stiffness and to the conjugation of the bonds within the molecule.

\section{3-2. Low Temperature Polymers}

Generally, plastic materials have shown relatively good low temperature resistance. They are attractive for cryogenic applications because of their low thermal conductivity as well as specific heat and good mechanical properties. However, their high coefficient of thermal expansion constitutes a definite disadvantage. This may be overcome by the addition of finely divided metals or mettallic oxides. ${ }^{20}$

Polytrifluoromonochloroethylene(KelF)has been used effectively at cryogenic temperature for many years for engineering applications. Although less ductile than at room temperature, the low crystalinity material still has approximately $5 \%$ elonga- tion at $-320^{\circ} \mathrm{F}$.

Closed-cell rigid plastic foams have been used in cryogenic insulation systems. The foams of most interest for such applications are polystyrene, epoxy, polyurethane and rubber. ${ }^{21)}$

Most commonly used cryogenic seals are made of fluorinated polymers but mylar and nylon have been found usable as gaskets from -323 to $350^{\circ} \mathrm{F}$.

Elastomers, with the exception of certain silicones and fluorosilicones which can operate as low as $-120^{\circ} \mathrm{F}$, generally have unsatisfactory mechanical properties due to extreme brittleness at temperatures below $-70^{\circ} \mathrm{F}$. Plastics, of low glass transition temperatures and high crystallinity are able to withstand much lower temperatures without sacrificing their original resiliency, hardness and impact strength.

\section{Future Trends}

\section{4-1. Thermally Stable Polymers}

A great deal of research effort is being expended toward the synthesis of new thermally resistant Polymers. The polybenzimidazoles can withstand temperatures of up to $500^{\circ} \mathrm{C}$ for long periods of time without softening and deterioration. One reason for their high thermal stability is the rigidity of the chains due to large aromatic recurring units. Other rigid molecules which are now being studied for possible applications in the field of high temperature resistant materials are based on other aromatic chains such as polyphenylene. ${ }^{22)}$

\section{Polyphenylene}

The latter cannot fold even at rather high temperatures because rotation about the carbon-carbon single bond between the para-combined phenylene rings can only lead to different angles between the planes of consecutive rings but not to a kink or bend in the main chain. The presently available polyphenylenes are characterized by low molecular weight but there is little doubt that future research will lead to the synthesis of high molecular weight polyphenyls, and consequently greatly improved mechanical properties. Another interesting way to arrive at chains made up of condensed rings is the synthesis of so-called ladder polymers. The first example of such a structure 
was prepared by exposing polyacrylonitrile to elevated temperatures which caused the formation of rows of six rings by an electron pair displacement.<smiles>C=CC(CC)CC(C=O)CC(C=O)CC(C=N)CC(C=O)CC(C=O)CC</smiles>

A black, completely infusible and insoluble material is obtained which corresponds in its structure to a linear graphite in which one carbon atom of every ring has been replaced by nitrogen. The rigidity and stiffness of chains as well as the fact that two bonds need to be broken in a ladder polymer instead of one as in conventional polymers, indicate that this type of material is very promising for space as well as for many industrial applications. One may therefore expect a great deal of activity in this area in academic as well as in commercial institutions.

\section{4-2. Solid Propellants}

Polymers are extensively used as binders for inorganic oxidizers in solid propellants. At the early stages of solid propellant chemistry, thermoplastic or thermosetting polymers were already used as binder fuel. They consisted of phenolic resins, polystyrene copolymers, cellulose polymers, styrene, butadiene-rubber, etc. ${ }^{23)}$

A desirable solid propellant binder should consist of a viscous fluid allowing easy mixing with the oxidizer (e. g. ammonium perchlorate). It is necessary after the mixing operation to transform the viscous slurry into a solid rubbery material. These requirements were met by polyurethanes and from 1954 until recently polyurethane was the most important solid propellant binder for rocket application. About six years ago a solid propellant using polybutadiene acrylic acid copolymer was developed. This polymer was the first of polybutadiene rubbers used in the solid rocketry area but later a number of other rubbery polymers were found. One of the most interesting in this category consists of polybutadiene terminated at both ends by carboxyl groups and synthesized by the "living polymer" technique. Solid propellant for future use in space mission must offer higher performance and at the same time withstand the special environmental conditions imposed by such missions. Jmproved performance will be obtained by the use of either better oxidizers or specially developed polymeric binders or both. New polymeric binders are required to make them compatible with high energy ingredients and permit simultaneously a high solid loading. Future developments of improved solid propellants will depend on the fact that planetary spacecraft intended to land on Mars, Venus, Mercury, Jupiter etc. must undergo a sterilization treatment to prevent contamination of planets with Earth organisms. If the sterilization requirements do not change, then the new propellants will have to withstand three 36 -hour cycles of heating at $145^{\circ} \mathrm{C}$ $\left(293^{\circ} \mathrm{F}\right)$ and retain high reliability. In order to operate at low temperature to which the solid propellant may be exposed in space the binder should exhibit a low glass transition temperature. Apart

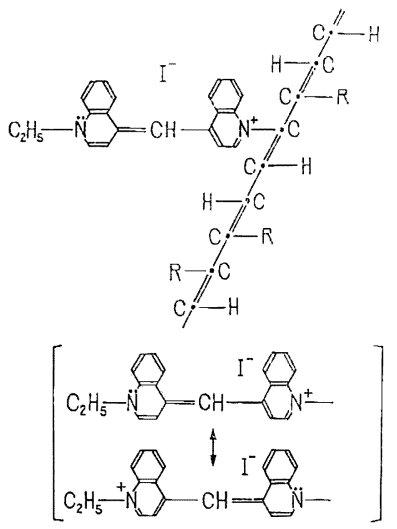

from the above conditions it will be necessary to have a binder undergoing a negligible vaporization loss in a high vacuum.

\section{4-3. Superconducting Polymers}

In 1950 a suggestion was made by $\mathrm{F}$. London ${ }^{24)}$ that some of the more cemplicated organic molecules might be able to exhibit, not semiconductivity but superconductivity. This idea was taken up in 1964 by W. A. Little ${ }^{25)}$ who postulated on the basis of the B.C.S. theory that a polymer of the structure shown above may exhibit superconductivity at room temperature. Synthesis of such a material would lead not only to tremendous developments in the polymer industry but also to a revolution in our own way of life. 
A superconducting polymer could solve a number of difficult space problems, in particular the prevention of communication blackout of a space vehicle during reentry. Although the synthesis of a superconducting polymer having a structure shown above is by no means an easy task, it is likely to be achieved in the future, and if indeed such polymers superconduct at room temperature, practically an unlimited number of applications on our planet as well as in space can be envisioned.

\section{References}

1) L. D. Jaffe: Chemical Engineering Symposium Series, 59, No. 40 (1963)

2) B. G. Achhammer, M. Tryon, G. M. Kline: Kunststoffe, 49, 600 (1959)

3) R.A. Mayer, N. J. Broadway, S. Palinchak: Battelle Memorial Institute, Radiation Effects Information Center, Rpt. 13, Columbus, Ohio, (1963)

4) S. Straus, L. A. Wall: J. Res., National Bureau of Standards, 60, 39 (1958)

5) r. F. Matacek: First Symposium Surface Effects on Spacecraft Materials, Wiley, New York, (1960)

6) S. L. Madorsky: J. Polymer Sci., 11, 491(1953)

7) R. R. Stromberg, S. Straus, B. G. Achhammer: J. Polymer Sci., 35, 355 (1959)

8) S.L. Madorsky, S. Straus: J. Res. National Bureau of Standards, 63A, 261 (1959)

9) E. A. DeWitt, S. Podlaseck, J. Suhorsky: Martin Co. Report RM-29, Baltimore, (1959)

10) N. Grassie: Trans. Farad. Soc., 49, 835 (1953)

11) S. L. Madorsky, V. E. Hart, S. Straus: J. Res.,
National Bureau of Standards, 60, 343 (1958)

12) S. Straus, S. L. Madorsky: J. Res., National Bureau of Standards, 61, 77 (1958)

13) D. J. Santeler: “Trans. 5th National Sympo sium on Vacuum Technology", 1 (1958)

14) E. A. DeWitt, S. Podlaseck, J. Suhorsky: Martin Co. Report RM-29, Baltimore, (1959.)

15) S. Straus, L. A. Wall: J. Res., National Bureau of Standards, 60, 39 (1958)

16) S. L. Madorsky, V. E. Hart, S. Straus, N. A. Sedlak: J. Res. National Bureau of Standards, 51, 327 (1953)

17) R. F. Freeman, R. A. Boundy, R. Harrington: Rubber and Plastics Age, 47, 777 (1966)

18) C. S. Marvel: "Polymer Preprints, ACS, New York Meeting”, 4, No. 2 (1963)

19) R. Poet: “20th Anniversary Technical Conference SPI”, (Feb. 1965)

20) H. L. Laquer: Report AECD, (Dec. 9, 1952)

21) "Mechanical Properties of Materials", Editors, R.W. Vance, W. M. Duke, Wiley, New York (1962)

22) H. Mark: J. Polymer Sci., C, Polymer Symposia, "Structure and Properties of Polymers", edited by A. V. Tobolsky

23) F. H. Hendel: Technical Memorandum No. 33 -254, Jet Propulsion Laboratory, California Institute of Technology, Pasadena (Oct. 1965)

24) F. London: "Superfluids", J. Wiley, New York (1950)

25) W. A. Little: J. Polymer Sci., C, Polymer Symposia, "Electrical Conduction Properties of Polymers", Edited by A. Rembaum and R. F. Landel.

\section{Journal of Pure and Applied Chemistry シンポジウム（東京・京都，1966） 特別号予約発注について}

国際高分子化学シンポシウムの特別講演が掲載される予定の Journal of Pure and Applied Chemistry の予約申込みを受付けます。頒価は決定していません が，若干安く入手できるはずです。予約が所定数に達しますと予約申込みは打ち 切らせていただきますので早めに下記へお申し込み下さい。

東京都中央区銀座東 5-2-4 本州ビル 4 階 電話 東京 (03)（543）3771（代表） 社団法人 高 分子 学 会 JPAC 特別号予約係あて 